\title{
The Influence of the Human Factor on the Success of the Localization Project of the Automated Technological Line for Wood Production
}

\author{
Radka Vaníčková \\ Institute of Technology and Business in České Budějovice, Faculty of Business Strategy, Department of \\ Management, Nemanická 436/7, 370 01, České Budějovice, Czech Republic
}

\begin{abstract}
The digital revolution has moved translation from the world of paper documents to the land of software, websites, multimedia and databases, giving rise to the concept of localization. The purpose of localization is a specific product that will look as if it was intended for a given target market, regardless of language, culture or country. The aim of the paper is to acquire an automated technological line for the cutting of large-area materials, especially chipboard and joints. The methods used were Stakeholder Analysis represented by a matrix structure in tabular form with a point scale ranging from 1 to 10 . In order to implement project feedback and subsequent controlling, another method was used, namely the Traffic Light Method. Through the acquired knowledge and finding out the influence of the human factor on the success of the project, it was proved that the success of completing a local project depends mainly on the role and competencies of the project manager in cooperation with the powers of individual members of the project team.
\end{abstract}

One of the main causes of project failure is inappropriate project management methods used, but also failure of human capital.

DOI: 10.18421/TEM101-01

https://doi.org/10.18421/TEM101-01

Corresponding author: Radka Vaníčková,

Department of Management, Institute of Technology and

Business in České Budějovice, České Budějovice,

Czech Republic.

Email: vanickovaradka@gmail.com

Received: 29 October 2020.

Revised: 28 December 2020.

Accepted: 06 January 2021.

Published: 27 February 2021.

(c) BY-NC-ND (C) 2021 Radka Vaníčková; published by UIKTEN. This work is licensed under the Creative Commons Attribution-NonCommercial-NoDerivs 4.0 License.

The article is published with Open Access at www.temjournal.com
Keywords - Localization project, methods Stakeholder analysis and Traffic light method, Belbin's typology of team roles, International Project Management Association, leadership.

\section{Introduction}

According to the international organization GALA (Globalization \& Localization Association), localization is defined as the process of adapting a specific product or content to a designated market or area [1]. The translation itself is only one part of the localization process. Other sub-localization processes include adaptation of image graphics to the target market, modification of content to suit consumer habits in other markets, conversion of names and units, use of correct local formats for dates, addresses and telephone numbers, implementation of local laws and regulations [2]. There are several reasons why the emphasis in the localization industry is on project management [3]. The primary reason is that the translation work itself is typically done in the form of projects [4]. The PMBOK project management manual defines a project as a temporary effort to create a unique product, service or result [5]. The result of the project can then be concrete or intangible [6]. Although repetitive elements may be present in some outputs and project activities [7], this repetition does not change the basic and unique characteristics of project work [8]. Significant projects can be managed in the same ways, but each project will ultimately be unique thanks to a different team of collaborators [9], other sources of translated text, situations or stakeholders [10].

Professional translation is an activity that is inherently highly outsourced [11]. Companies and customers outsource this activity because translation is not one of their key activities [12]. In the model, an organization that needs to translate its product into one or more foreign languages assigns a project to a Language Service Provider (LSP), which subcontracts the project to individual translators 
(self-employed/freelancers). LSP can also subcontract the project to agencies or companies dealing with translation into only one language, the so-called vendors who employ in-house translators or work with translators in a given country [13]. LSPs also outsource services such as DTP (desktop publishing), which is the graphic editing of documents and manuals, working with images, etc. [14].
The model in Figure 1 demonstrates the paradox of the functioning of the translation industry, where most translation agencies do not perform the translation itself, but subcontract it to others. The rhetorical question arises: "What kind of work do the agencies do?" The answer is that they subcontract with respect to time and budget according to the requirements of the client/customer. The terms "translation agency" or LSP are not entirely correct, and neither of them reflects the key competences of a translation company.

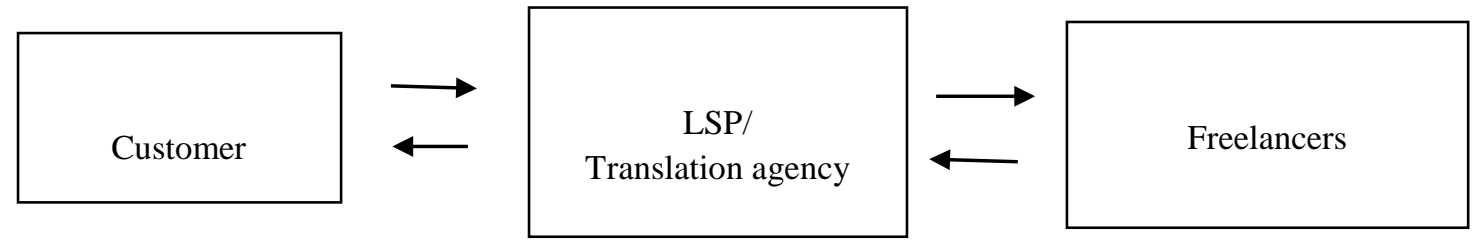

Figure 1. Outsourcing model (own proccesing)

The real focus of these companies is vendor management, sales management and especially project management. The role of the sales and marketing department is to acquire, develop and maintain a client base. Vendor management includes the identification and qualification of language service providers, quality control of work and active search for new potential subcontractors. The task of project management is to apply the knowledge, skills, tools and techniques of project management so that project goals are met [15]. In the opinion of the author's paper, in the current cyclical period, the form of project management, which is important in the competitive struggle of localization companies, is no longer used to a greater extent. Machine translation technologies using neural networks are coming to the fore. The company that is the first to develop a machine translation tool with a high degree of precision will gain a predominant competitive advantage in the global and local market in the respective industry [16].

One of the main causes of project failure can be seen in inappropriately selected and used project management methods, but also in the failure of human capital [17], e.g. closed formal communication between people [18], between members of the project team/stakeholders in the project, etc. sub-partners.

If the three-imperative of the project is fulfilled, there are other team dysfunctions, which include e.g. lack of trust, low diversity and involvement of individual members in solving tasks, fears and fears of conflicts/failures in the competence of the assigned roles of the project team, intentional avoidance of responsibility [19], indifference to project results/outputs, low motivational element, limited involvement, side effects and etc. [20].

\section{Methodology}

Current project management standards, e.g. The Project Management Body of Knowledge (PMBOK Guide) offers a general framework of methodology that can be applied in any industry.

The PMBOK methodology maps project management processes into five process groups (initiation, planning, execution, monitoring, control, termination) and nine knowledge areas:

1) Integration management

2) Scope management

3) Project time management

4) Cost management

5) Project quality management

6) Human resources management

7) Project communications

8) Risk management

9) Project procurement management

Managing localization or projects in any other industry requires adapting these skills to the industry. In the practical application of some elements or the whole PMBOK methodology to localization practice, managers are dependent on their own knowledge. Estimating and managing time and costs in highly creative work on a translation project can be an impulse to make several hypotheses, e.g. "How can we estimate the duration of the translation of a specific task and its price?", "What units of measure will we use to create translation pricing structures?" "Will we use words, characters, sentences, hours, pages, or other terminology?”

In order to be able to respond eruditely, we have to identify the basic variables that can affect the length of a localization project, including the creation of a methodology to determine the complexity of the 
project. The role of the project manager is to determine, through the acquired knowledge, professional skills and own professional judgment, all unknown/variables in order to achieve the best possible result that meets our expectations.

The aim of the project was the acquisition of an automated technological line for the cutting of largearea materials, especially DTD (chipboard) and joints, which enter in standard or specifically defined combined formats of furniture production. The technological line project was to provide the following benefits:

1) Ensuring sufficient production capacity of the 60 $\mathrm{m} 3$ cut in two-shift operation for own production.

2) Optimization of the formatting process to achieve maximum yield and obtain savings on the material input side and increase the yield by about 5\%.

3) Accurate registration and automatic marking of formatted materials in terms of IS (information systems).

4) Automatic processing and disposal of cuttings.

5) Extension of the possibility by special cutting plans due to the production of solid wood furniture and chipboard.

The project of acquisition of the technological line used the Stakeholder Method applicable to the application in the project management, because in the event that any interested party (stakeholders) was omitted, the project may not be successfully completed. This method offers answers to the following research questions:

- Who are the stakeholders to the researched localization project?

- What are the professional interests and demands of the stakeholders in the project?

- What opportunities and threats does the stakeholder have/are concerned about the project?

Stakeholders are usually groups of people/individuals who are interested in or interested in the success of the project. Stakeholders can generally be divided according to their importance into two groups, namely the primary grouping, e.g. owners, investors, employees, customers (current and potential), business partners, especially suppliers, etc. and secondary coalitions, e.g. public, government institutions and self-governing bodies, competitors, etc. The Stakeholder Method uses a matrix structure in the form of a tabular expression with a point rating in the range from 1 to 10 . The higher the point value obtained, the more useful it is to assign a greater influence to the relevant stakeholder with respect to a particular project. Art according to managerial and decision-making powers consists in an objective and sophisticated classification of key groups/persons with whom it is essential to work closely.

In order to implement project feedback and controlling, it is useful to use another method in the project, namely the Traffic Light Method, which aims to evaluate benefits/impacts, including the formulation of proposals and recommendations for change/adjustment/innovation with a view to future development, expectations/ challenges/impulses and signals in industry with regard to the addressed issues of project management with a focus on automated systems. Ways to evaluate the benefits of feedback, including controlling, are e.g. by formulating research questions: "What was done during the project?", "What was not done during the project and why?", "What should be done differently/better in the future?", "What was overlooked in the project and why?", "What was less time/attention/importance /seriousness given to the project and for what reason?”

Based on the research questions interpreted above, it is permissible to colour-code the passages in the project, as in the case of a traffic light, with red $\rightarrow$ what should not be done next time, orange $\rightarrow$ what needs to be considered more carefully, or do not repeat and green signalling $\rightarrow$ what was done well and should be implemented next time, e.g. in a subsequent period of time.

\section{Results and Discussion}

First, it is necessary to distinguish whether it is a project or a normal routine activity of a production nature. This fact is reflected in Table 1.

Table 1. Differences between the common production task and the project (own processing according to [21])

\begin{tabular}{|c|c|c|}
\hline Aspect & $\begin{array}{c}\text { A common } \\
\text { production task }\end{array}$ & Project \\
\hline Role & $\begin{array}{l}\text { Known } \\
\text { (there is } \\
\text { experience) }\end{array}$ & $\begin{array}{c}\text { Unknown } \\
\text { (experiences are } \\
\text { not available) }\end{array}$ \\
\hline $\begin{array}{c}\text { Employee } \\
\text { involvement }\end{array}$ & Permanent & Transitional \\
\hline Team roles & Known & Creating, unknown \\
\hline Relationships & $\begin{array}{l}\text { Cooperation } \\
\text { (given by the } \\
\text { system) }\end{array}$ & $\begin{array}{c}\text { They are created in } \\
\text { the system } \\
\text { (in the research } \\
\text { team) }\end{array}$ \\
\hline Time range & Long-term & Limited/final \\
\hline $\begin{array}{l}\text { Attitude to } \\
\text { change }\end{array}$ & $\begin{array}{c}\text { Desirable for } \\
\text { manufacturing } \\
\text { activities }\end{array}$ & $\begin{array}{c}\text { Necessary for } \\
\text { production activity }\end{array}$ \\
\hline
\end{tabular}


It is clear from Table 1 that this was a project. The basic precondition for the success of the project is the appropriate composition of the project team. The project team leader should primarily have the professional knowledge, skills and personal characteristics that are relevant to the performance of the function. This member should have both a team spirit and a certain degree of tolerance towards other colleagues in the team. Another prerequisite for the functionality of teamwork is the determination of the role in order to fulfill the assigned tasks, including the support of good interpersonal relationships, a favourable atmosphere in the workplace and the culture of the business entity's environment. In order to find out these facts, Table 2 was created, which shows the difference between the executive team and the group.

Table 2 showed that it was in fact an executive team, not a group. A key element in building a team is the project manager, who is responsible for the team and the role is to:

Table 1. Differences between executive team and group (own proccesing according to [22])

\begin{tabular}{|c|c|c|}
\hline Characteristic features & Group & Executive team \\
\hline $\begin{array}{l}\text { What about the interests of } \\
\text { members? }\end{array}$ & $\begin{array}{l}\text { Most members follow their own } \\
\text { hobbies. }\end{array}$ & Everyone holds together. \\
\hline What about goals? & Various goals are pursued. & They all pursue the same goal. \\
\hline What is the priority? & $\begin{array}{l}\text { Belonging to the group is } \\
\text { subordinate to personal interests. }\end{array}$ & $\begin{array}{l}\text { Belonging to the team has the } \\
\text { highest priority. }\end{array}$ \\
\hline $\begin{array}{l}\text { How it looks } \\
\text { with the organization? }\end{array}$ & $\begin{array}{c}\text { The organization is relaxed and } \\
\text { non-binding. }\end{array}$ & $\begin{array}{l}\text { The organization is strong } \\
\text { /binding/stable. }\end{array}$ \\
\hline What is the motivation? & $\begin{array}{l}\text { Motivation comes from outside } \\
\text { (must be). }\end{array}$ & $\begin{array}{l}\text { Motivation comes from within } \\
\text { (wants to). }\end{array}$ \\
\hline Who and to whom competing? & $\begin{array}{l}\text { Individuals compete } \\
\text { each other. }\end{array}$ & $\begin{array}{c}\text { The competition is focused } \\
\text { outwards. }\end{array}$ \\
\hline How to communicate? & $\begin{array}{l}\text { It communicates in part } \\
\text { openly, partly hiddenly. }\end{array}$ & $\begin{array}{c}\text { Information process a } \\
\text { feedback is ongoing openly. }\end{array}$ \\
\hline How is it mutual trust? & $\begin{array}{l}\text { Mutual trust in } \\
\text { group is usually few. }\end{array}$ & $\begin{array}{l}\text { Strong trust between members } \\
\text { team each other. }\end{array}$ \\
\hline
\end{tabular}

1. Focus on solving problems/milestones/risks YES, the hypothesis was fulfilled mainly from a technical point of view. Adherence to deadlines was solved using a matrix based on the Eisenhower principle in order to eliminate the stress of key people in the project team.

2. Openness to the opinions of other members of the project team, including an appeal to determination - YES, the hypothesis was confirmed especially with regard to the supplier XYZ.

3. Targeted orientation to the needs and wishes of the customer - NO, the hypothesis was rejected, because in the examined project the assignment was assessed as insignificant.

4. Negotiations for the benefit of all stakeholders YES, the hypothesis was approved, as the project was implemented within a predetermined time with respect to the identification of the threeimperative.
5. Achieving the best results - YES, the hypothesis was ratified, the synergy was confirmed.

6. Searching for opportunities for self-development - YES, the hypothesis was subjectively confirmed with reference to the professional growth and professional development of the project team.

7. Leadership by personal example - YES, the hypothesis was sealed directly from the mouth of the project manager, who personally claims responsibility for meeting the objectives defined in the local project.

From the point of view of the project team, it is beneficial to point out the fact that the project team leader was directive - appointed by the company's top management - see the organizational structure of the automated line project shown in Figure 2 below. 


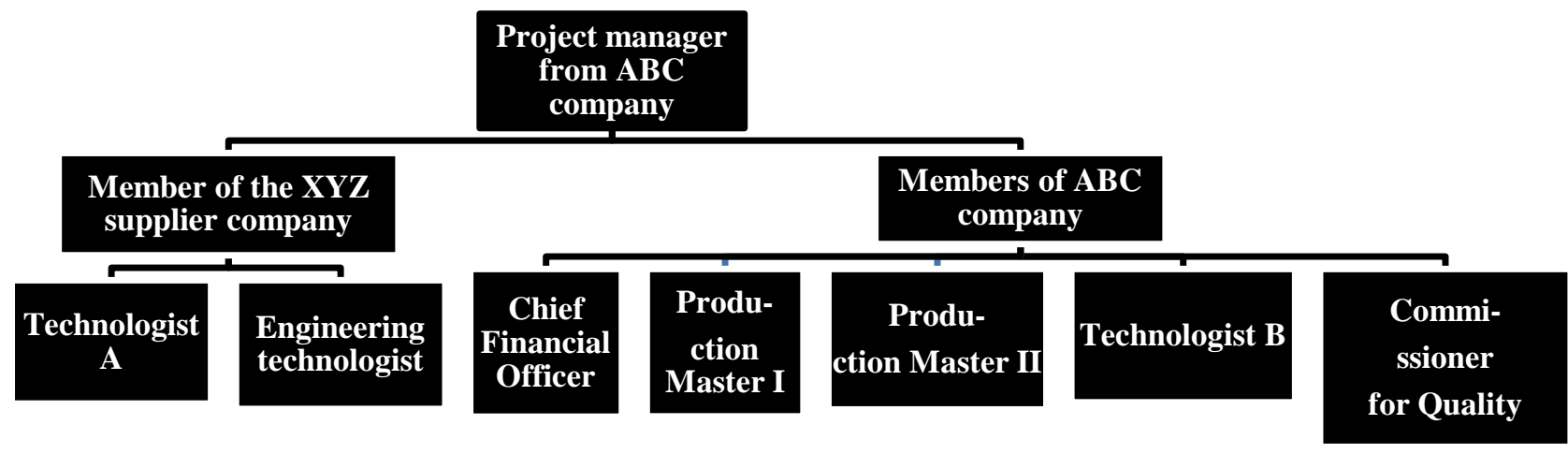

Figure 2. Organizational structure of project team members (own proccesing)

Based on Belbin's typology of team roles, with regard to participation in the project, roles were defined according to the personality traits of individual members of the project team:

- technologist A $\rightarrow$ extroverted and erudite personality, communicative and practically conflict-free individual with knowledge and experience of partial issues of project management. Role: SPECIALIST;

- engineering technologist $\rightarrow$ partly conflicting personality, however erudite and confident personality, indispensable for the project team, less communicative with increased ego. Role: INNOVATOR;

- project team leader $\rightarrow$ appointed on the basis of an order from ABC's top management. Personality applying increased management with an emphasis on control activities. A person avoiding conflict/dispute resolution in the workplace with a predominance of ordered communication. Role: REALIZER;

- $\mathrm{CFO} \rightarrow$ according to temperament rather introvert, nevertheless adaptable, beneficial for the company, moderately communicative. In terms of fulfilling the three-imperative, entrusted with obtaining resources. Role: RESOURCE SEARCHER;

- production foreman I $\rightarrow$ mostly introverted personality, fulfilling only the orders of the team leader. Working knowledge of the operation of production activities are excellent, personal aversion to the delegation of tasks. Role: MONITOR EVALUATOR (rather in a negative sense);

- master of production II $\rightarrow$ extrovert personality, technically very capable, positively active in the team, generally indispensable, strongly communicative knowledgeable of production issues at a high professional level. Role: REALIZER;
- technologist $\mathrm{B} \rightarrow$ extrovert personality with many years of work experience and expertise in the woodworking industry at an excellent level. An individual with concerns about any changes/innovations in the production process, however communicative, often influenced by stressful factors of the internal and external work environment. Role: TEAM WORKER;

- representative for quality $\rightarrow$ personality introverted so-called "up to the number of project team members", without professional experience with wood production, in the team at the request of the project manager. At $\mathrm{ABC}$, a new core employee with no ties to the external environment. Role: TEAM WORKER.

The above facts need to be taken into account and approached in order to formulate summary and partial conclusions. In the case of a project, subjective evaluation by management is important, as well as objective evaluation by leadership in terms of leadership in conjunction with the necessary competencies to resolve potential conflicts in the project team, including selecting a suitable project team member, defining interpersonal powers necessary for business negotiations, presentation skills, cooperative style of work, etc., including extensive technical skills, such as reading drawing documentation, capacity calculations of the automated line, etc. hard and soft key parameters.

Based on the typology of team roles of individual members of the project team, it can be stated that the team achieved higher productivity and at the same time had a high degree of autonomy within the entire company. The aim was to prepare for the smooth operation of the production of formatted chipboards. In terms of the influence of the human factor on the success of the project, the analysis of stakeholders in the project can be interpreted to some extent - see Table 3. 
It is clear from Table 3 that the most important stakeholder with regard to the obtained point values was the top management and the project team, on which the success of the course, implementation and finalization of the project depended.
The influence of the human factor on the success of the project has been proven and in the opinion of the author of the paper it is essential and difficult to replace.

Through the Traffic Light Method it was found:

Table 2. Stakeholder analysis in the project (own proccesing)

\begin{tabular}{|c|c|c|c|c|}
\hline $\begin{array}{c}\text { Stakeholders } \\
\text { ABC }\end{array}$ & Expectation & Goals & $\begin{array}{c}\text { Strong } \\
\text { Causes of strength }\end{array}$ & Evaluation \\
\hline $\begin{array}{c}\text { Owners of ABC } \\
\text { company }\end{array}$ & $\begin{array}{l}\text { Permanently stable position in } \\
\text { the field on the market } \\
\text { The prestige of the company }\end{array}$ & $\begin{array}{l}\text { Investment } \\
\text { Profit }\end{array}$ & $\begin{array}{l}\text { Financial } \\
\text { capital }\end{array}$ & 8 \\
\hline $\begin{array}{c}\text { Top } \\
\text { management }\end{array}$ & $\begin{array}{l}\text { Prestige in the company } \\
\text { Compliance with the } \\
\text { requirements of owners }\end{array}$ & $\begin{array}{l}\text { Self-satisfaction } \\
\text { Salary motivation } \\
\text { Self-realization }\end{array}$ & $\begin{array}{c}\text { Finance } \\
\text { Own initiative } \\
\text { Responsibility }\end{array}$ & 9 \\
\hline $\begin{array}{c}\text { Management } \\
\text { (all other levels) }\end{array}$ & $\begin{array}{l}\text { Responsibility } \\
\text { Increase in production } \\
\text { Market control }\end{array}$ & $\begin{array}{l}\text { Salary motivation } \\
\text { Social prestige } \\
\text { Self-realization }\end{array}$ & $\begin{array}{l}\text { Market knowledge } \\
\text { Self-realization }\end{array}$ & 8 \\
\hline Project team & $\begin{array}{l}\text { Responsibility for the } \\
\text { Project Fulfillment } \\
\text { of the three-imperative }\end{array}$ & $\begin{array}{l}\text { Three-imperative } \\
\text { Target rewards }\end{array}$ & $\begin{array}{c}\text { Experiences } \\
\text { IPMA certification }\end{array}$ & 9 \\
\hline Employees & $\begin{array}{c}\text { Securing job positions } \\
\text { Good salary conditions } \\
\text { Communication with } \\
\text { management }\end{array}$ & $\begin{array}{l}\text { Job Health and } \\
\text { safety compliance } \\
\text { Favorable salary } \\
\text { conditions }\end{array}$ & $\begin{array}{l}\text { Raising living standards } \\
\text { Leaving for the } \\
\text { competition } \\
\text { Elimination of conflicts }\end{array}$ & 5 \\
\hline $\begin{array}{l}\text { Technology } \\
\text { Suppliers } \\
\text { (XYZ) }\end{array}$ & $\begin{array}{l}\text { Cooperation with the } \\
\text { company on other } \\
\text { projects Profit }\end{array}$ & $\begin{array}{l}\text { Permanent cooperation } \\
\text { with the company }\end{array}$ & $\begin{array}{c}\text { Corporate } \\
\text { development }\end{array}$ & 6 \\
\hline $\begin{array}{l}\text { DTD suppliers, } \\
\text { etc. }\end{array}$ & $\begin{array}{l}\text { Larger production } \\
\text { More customers }\end{array}$ & $\begin{array}{l}\text { Permanent sales } \\
\text { Better furniture }\end{array}$ & $\begin{array}{c}\text { Profit } \\
\text { Certification according } \\
\text { to ISO } 9001\end{array}$ & 5 \\
\hline $\begin{array}{l}\text { Company } \\
\text { customers }\end{array}$ & $\begin{array}{l}\text { Declared quality of DTD } \\
\text { Ecology (release of free } \\
\text { CH2O) Price }\end{array}$ & $\begin{array}{l}\text { Quality DTD without } \\
\text { leakage of free } \mathrm{CH} 2 \mathrm{O}\end{array}$ & $\begin{array}{l}\text { Quality furniture } \\
\text { Compliance with ISO } \\
9001\end{array}$ & 7 \\
\hline $\begin{array}{c}\text { State } \\
\text { institutions } \\
\text { (government, } \\
\text { EU) }\end{array}$ & $\begin{array}{l}\text { Business development } \\
\text { Tax collection }\end{array}$ & $\begin{array}{l}\text { Increasing the living } \\
\text { standards of the } \\
\text { population in the region }\end{array}$ & $\begin{array}{l}\text { Legislation and } \\
\text { legislative changes in } \\
\text { the field of business, } \\
\text { Regulation }\end{array}$ & 8 \\
\hline $\begin{array}{l}\text { Public and } \\
\text { region }\end{array}$ & $\begin{array}{c}\text { Ethical principles, transparent } \\
\text { business environment, } \\
\text { consumer protection }\end{array}$ & $\begin{array}{l}\text { Development of the } \\
\text { region Increasing } \\
\text { traffic to the region }\end{array}$ & $\begin{array}{l}\text { Development of the } \\
\text { region }\end{array}$ & 3 \\
\hline
\end{tabular}

\section{What should not be repeated in the future, e.g.}

- minimal communication with the company's employees (see the evidence in Table 3),

- low acceptance of milestones as checkpoints of adherence to the three-imperative,

- erudite choice of project team members influenced by the company's top management.

\section{Acts that deserve consideration and subsequent decision in terms of acceptance/rejection:}

- consider whether the directive appointment of a project manager is effective or not, even though in the case of the project under review the choice was considered,
- apply to a greater extent the Belbin typology of team roles to the project as a possible/alternative change implemented in individual members of the project team during the life of the project (even in the case of external members of the project team),

- certify selected personalities from the company $\mathrm{ABC}$ according to IPMA in order to promote competencies in the company in order to support success in all implemented projects.

What has been done well and should be realized in the future:

- incorporate a system of ISO 9001 series standards into the project, 
- take into account the project in relation to the current corporate strategy,

- implement the above-mentioned analyzes (Stakeholder Analysis and Traffic Light Method) into project management.

\section{Conclusion}

From a summary point of view, it is indisputable that the influence of the human factor on the success of the project is significant. Without human resources, especially a skilled and sophisticated workforce, it is not possible to achieve positive results for projects and to finalize all project stages in a logical sequence. The supporting tool is IPMA certification, through which competencies in the company can be promoted in order to achieve success for all members of the project team and projects with respect to the management style approach in combination with leadership in the context of Belbin's team roles.

The acquired knowledge regarding the influence of the human factor on the success of the localization project shows that the quality of the project depends mainly on the role and competencies of the project manager in cooperation with the powers of individual members of the project team. Furthermore, it is useful to identify key factors affecting the success of project teams, such as:

- precise formulation of goals and fulfillment of the three-imperative,

- defining the roles of individual members of the project team, the degree and manner of effective communication, project milestones, providing feedback and controlling, etc.,

- preparation of individual members to fulfill defined tasks according to the identification of team roles (according to transferable knowledge and skills),

- support of the company's top management according to the scope of competencies of the project team leader,

- motivation of project team members to perform, their own commitment and usefulness,

- transfer of ownership between all members of the project team on an equal footing.

Project failure is most often measured by the triple imperative, which is cost, quality and time. In today's turbulent times of the 21st century, communication between people, and therefore between members of project teams, is an increasing phenomenon, which "goes hand in hand" with inappropriate assignment of team roles for individual members in the context of the project goal and business strategy. The main causes of project failure are poorly identified project management methods, including human capital failure. In the case of limited communication inside and outside with all stakeholders and target stakeholders, there is a risk of conflict between partners, disruption of interpersonal relationships, restrictions on cultivating the work environment, including communication and sharing of work tasks and work responsibilities.

The influence of the human factor on the success of the project can be described as crucial, as it is part of the context of the three-imperative. One of the indispensable sources is human sources identified in terms of quantity, e.g.by number, etc., as well as in qualitative terms, e.g. by acquired skills and practical skills.

The aim of the paper is to point out the essential influence of the human factor involved in the success of the project in the context of applicable scientific methods of qualitative research project management, including consideration of alternatives to possible causes of failure in local projects.

\section{Acknowledgements}

The contribution is part of the project ERASMUS +, KA 205 Strategic Partnerships for Youth, Cooperation for innovation and the exchange of good practices. Project titled "Closing the Loop Along with the Youth".

\section{References}

[1]. Mahajan, G., \& Chaudhary, N. (2020). Improving Bug Localization using IR-based Textual Similarity and Vectorization Scoring Framework. Int. J. Advance Soft Compu. Appl, 12(2).

[2]. Gnoni, M. G., Bragatto, P. A., Milazzo, M. F., \& Setola, R. (2020). Integrating IoT technologies for an "intelligent" safety management in the process industry. Procedia Manufacturing, 42, 511-515.

[3]. Hrušecká, D., Lopes, R. B., \& Juřičková, E. (2019). Challenges in the introduction of AGVS in production lines: Case studies in the automotive industry. Serbian Journal of Management, 14(1), 233-247.

[4]. Wen, Q., \& Qiang, M. (2019). Project managers' competences in managing project closing. Project Management Journal, 50(3), 361-375.

[5]. Edwards, L., Hayes, S., Penny, S., Lakshmikanth, S. B., Sergeyev, A., \& Azizi, S. M. (2016, April). Automated stacker system design and development: Structural support, end-effector, and control subsystems. In 2016 Annual IEEE Systems Conference (SysCon) (pp. 1-6). IEEE.

[6]. Gorod, A., Hallo, L., \& Nguyen, T. (2018). A systemic approach to complex project management: Integration of command-and-control and network governance. Systems Research and Behavioral Science, 35(6), 811-837.

[7]. Watts, B., Lawrence, R. H., Drawz, P., Carter, C., Shumaker, A. H., \& Kern, E. F. (2016). Development and implementation of team-based panel management tools: filling the gap between patient and population information systems. Population health management, 19(4), 232-239. 
[8]. Di Franco, A., Hogg, K. E., Calò, A., Bennett, N. J., Sévin-Allouet, M. A., Alaminos, O. E., ... \& Guidetti, P. (2020). Improving marine protected area governance through collaboration and coproduction. Journal of Environmental Management, 269, 110757.

[9]. Seniwongse, S. (2019). Teamwork in successful construction management of road improvement projects. ISEC 2019 - 10th International Structural Engineering and Construction Conference.

[10]. Gruden, N., \& Stare, A. (2018). The influence of behavioral competencies on project performance. Project Management Journal, 49(3), 98109.

[11]. Vaníčková, R. (2019). New functionality, security and protection of CCTV systems: technological progress and digital society development. In SHS Web of Conferences (Vol. 71, p. 03003). EDP Sciences.

[12]. Rothaermel, T. F. (2015). Strategic Management. 2. ed. New York: McGraw-Hill Education.

[13]. Ilyas, M., \& Khan, S. U. (2016). An Exploratory Study of Success Factors in Software Integration for Global Software Development Vendors. Journal of Proceedings of the Pakistan Academy of Sciences: A Physical and Computational Sciences, 53(3), 239253.

[14]. Luo Huilan, \& Yue Liangliang. (2020). Image description of cross-layer multi-model feature fusion and causal convolution decoding. Chinese Journal of Image and Graphics , 25 (8), 1604-1617.
[15]. Bočková, K., Lajčin, D., \& Lengyelfalusy, T. (2020). Is Project Manager's Age like a Wine? A Case Study in Petrochemical Industry in EU Countries. TEM Journal, 9(1), 242-248.

[16]. Liew, C., On, C. K., Alfred, R., Guan, T. T., \& Anthony, P. (2020, March). Real time mobile based license plate recognition system with neural networks. In Journal of Physics: Conference Series (Vol. 1502, No. 1, p. 012032). IOP Publishing.

[17]. Root-Bernstein, M. (2020). Tacit working models of human behavioural change I: Implementation of conservation projects. Ambio. 49(10), 1639-1657.

[18]. Colapinto, C., Jayaraman, R., \& La Torre, D. (2020). Goal programming models for managerial strategic decision making. In Applied Mathematical Analysis: Theory, Methods, and Applications (pp. 487-507). Springer, Cham.

[19]. Erskine, M. A., Khojah, M., \& McDaniel, A. E. (2019). Location selection using heat maps: Relative advantage, task-technology fit, and decision-making performance. Computers in Human Behavior, 101, 151-162.

[20]. Wei, Q., Zhang, J., Zhu, G., Dai, R., \& Zhang, S. (2020). Retailer vs. vendor managed inventory with considering stochastic learning effect. Journal of the Operational Research Society, 71(4), 628-646.

[21]. Posner, K., \& Applegarth, M. (2006). Projektový management. 1. vyd. Praha: Portál.

[22]. Krüger, W. (2004). Vedení týmů: jak sestavit, organizovat a povzbuzovat pracovní tým. Grada Publishing as. 